Asia Proceedings of Social Sciences

(APSS)

www.readersinsight.net/APSS

\title{
Distinctive Comparison of Consumers' Mobile Payment Adoption between China and Malaysia
}

\author{
Phuah Kit Teng \\ Faculty of Business, Communication and Law, Inti International University \\ Malaysia

\section{Bernard Lim Jit Heng} \\ Faculty of Business, Communication and Law, Inti International University \\ Malaysia

\section{Siti Intan Nurdiana Wong Abdullah}

Faculty of Economic and Management, Universiti Putra Malaysia Malaysia

*Corrosponding author's Email: kitteng.phuah@newinti.edu.my

Peer-review under responsibility of $4^{\text {th }}$ Asia International Conference 2018 editorial board (http://www.utm.my/asia/our-team/) (C) 2018 Published by Readers Insight Publisher, lat 306 Savoy Residencia, Block 3 F11/1,44000 Islamabad. Pakistan, info@ readersinsight.net 


\section{Research Highlights}

The emergence of mobile payment providers such as Alipay and WeChat Pay has raised the interest in studying the adoption of mobile payment and assessment on the prediction of consumers' intention. Due to insufficient research on cross-country comparison, this study aims to identify the differences in mobile payment adoption between China and Malaysia. Perceived usefulness, perceived security, perceived ease of use and attitude from Theory of Acceptance Model and Theory of Reasoned Action were used to analyse the intention to adopt mobile payment. Based on the results, perceived security seems to differ for the two countries while other factors have similar results. This study will definitely offer a fresh perspective to academics and practitioners in terms of exploring the propect of mobile payment in business trasnsactions.

\section{Graphical A bstract}

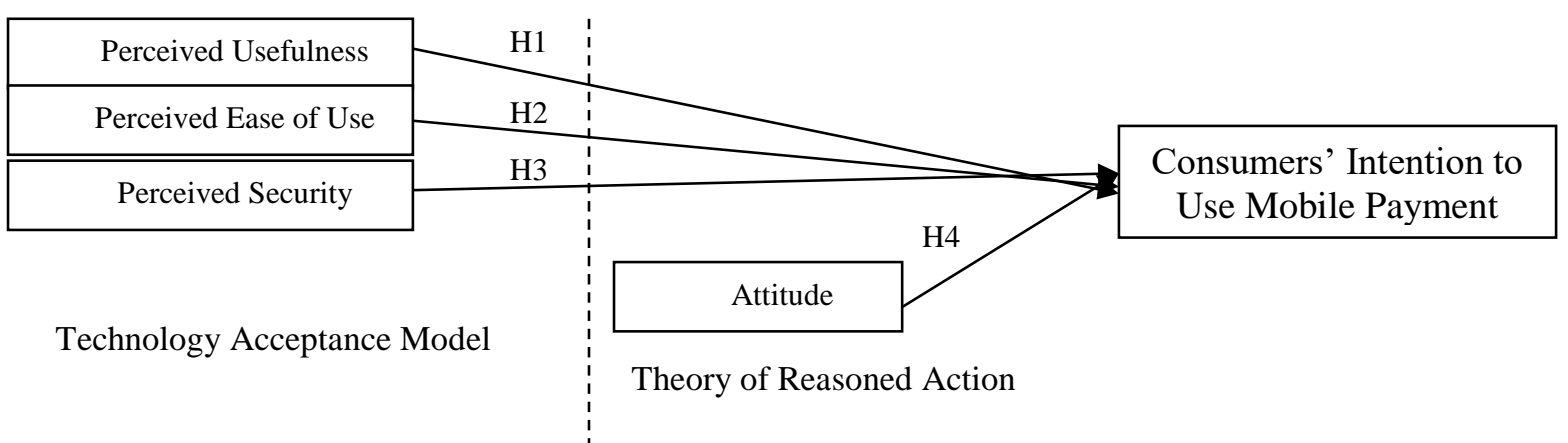

Source: Adapted model from Davis et. al., (1989) and Ajzen (1991)

\section{Research Objectives}

As the adoption for mobile payment is not the same for different continents and some countries still prefer conventional cash for transaction, this raises the queries on the progress of mobile payments for different countries around the world. Thus, this research is focuses on discovering the relationship between the different factors in Theory of Reasoned Action such as attitude and Technology of Acceptance Model (TAM) such as perceived usefulness, 


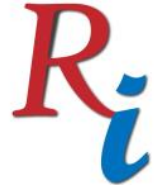

\section{Asia Proceedings of Social Sciences \\ (APSS) \\ www.readersinsight.net/APSS}

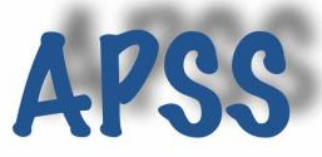

perceived ease of use and perceived security that may influenced China and Malaysia consumers' usage intention towards mobile payment.

General Objetive:

To study the China's and Malaysia's consumers' intention to use mobile payment .

Specific Objectives:

1. To determine the factors which influence consumers' intention to use mobile payment.

2. To distingush the adoption differences between China's and Malaysia's consumer in using mobile payment for business transactions.

\section{Methodology}

Theory of Reasoned Action (TRA) and Technology Acceptance Model (TAM) were used as the basis to illuminate consumer usage intentions on mobile payment. Data were collected from respondents in Nanjing, China and Klang Valley, Malaysia. The respondents are consumers who shop for electrical appliances since mobile payment is widely used in electrical shops. The sampling method used in this research is stratified random sampling where researchers will approach every 3 rd customer to fill up a personal administered survey. A total of 384 respondents from each location were surveyed and the data were analyzed using descriptive analysis, reliability tests and multiple regression analysis. These statistical measurement is relevant in assessing the relationship between the specified factors (attitude, perceived usefulness, perceived ease of use and perceived security) and consumers' usage intention.

\section{Results}

Based on the The Cronbach's alpha value from both countries, the figures suggested that the variables such as attitude, perceived usefulness, perceived ease of use and perceived security are within an acceptable range. This indicates that the model is reliable and fit for this study. 


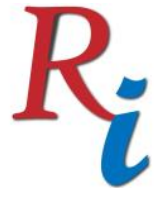

Asia Proceedings of Social Sciences

(APSS)

www.readersinsight.net/APSS

The multiple regression results indicated that atttude, perceived usefulness and perceived ease of use is significant with China's consumers' intention to use mobile payment and the same result is found in Malaysia. The findings are significant with past researches by Barutce (2008) and Cho \& Sagynov (2015). The only difference is that perceived secutity is significant for Malaysia but not China. This is due to the initial established trust and confidence that China had developed over the years (Zhou, 2013). As for Malaysia, perceived security is important in determining the consumers' intention to use mobile payment due to cautious on potential loss money or misuse of information from doubtful transactions (Bauer et al., 2005).

\section{Findings}

To engage more consumers into mobile payment, the result indicated that service providers will need to provide strong incentive especially for new users, more interactive use of system applications and hassle-free interface for the softwore application of mobile payment. In additions, continuous innovation in improving the security and promotional efforts are also relevant in convincing new users to utilize mobile payment applications. Assurance and reliability of mobile payment should be assured by service providers during their promotional campaign. This is relevent with the promotion goal of fully converting into mobile payment for business transactions.

\section{Acknowledgement}

The authors would like to thank INTI International University for giving them an opportunity to undertake the study. 


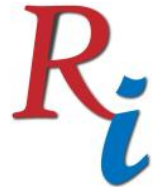

\section{Asia Proceedings of Social Sciences \\ (APSS) \\ www.readersinsight.net/APSS}

\section{References}

Ajzen, I. (1991). The theory of planned behavior. Organizational Behavior and Human Decision Processes, 50, 179-211.

Bauer, H., Barnes, S., Reichardt, T., \& Neumann, M. (2005). Driving consumer acceptance of mobile marketing: a theoretical framework and empirical study. Journal of Electronic Commerce Research, 6(3), 181-192.

Cho, Y. C., \& Sagynov, E. (2015). Exploring factors that affect usefulness, ease of use, trust, and purchase intention in the online environment. International Journal of Management \& Information Systems, 19(1), 21-36.

Davis, F. D., Bagozzi, R. P., \& Warshaw, P. R. (1989). User acceptance of computer technology: A comparison of two theoretical models. Management Science, 35(8), 982-1003.

Zhou, T. (2013). An Empirical Examination of Continuance Intention of Mobile Payment Services. Decision Support Systems, 54, 1085-1091. 